\title{
Antioxidant-rich Tamarindus indica L. leaf extract reduced high-fat diet-induced obesity in rat through modulation of gene expression
}

Syed Abdul Kuddus ${ }^{1}$, Mazharul Islam Bhuiyan', Nusrat Subhan', Md Hasanuzzaman Shohag ${ }^{1}$, Aura Rahman², Muhammad Maqsud Hossain ${ }^{2}$, Md Ashraful Alam ${ }^{1 *}$ and Ferdous Khan ${ }^{1 *}$ (D)

\begin{abstract}
Background: Different parts of the medicinal plant Tamarindus indica $L$. are full of phytochemicals that are able to reduce elevated blood pressure, blood sugar and lipids. These pharmacological effects are due to the presence of antioxidant type compounds in those parts of the plant. This study was aimed to explore the molecular mechanism of anti-obesity effects of ethanolic extract of T. indica L. leaves (TILE) through the evaluation of biochemical parameters and gene expression analysis in high-fat diet (HFD) consuming Wistar rats.
\end{abstract}

Methods: Male Wistar rats were supplied with a standard diet (SD), or HFD, or HFD with $100 \mathrm{mg} / \mathrm{kg}$ or $200 \mathrm{mg} / \mathrm{kg}$ or $400 \mathrm{mg} / \mathrm{kg}$ TILE for 8 weeks. The body weight, liver weight, fat weight, plasma lipids, and oxidative stress-related parameters were measured. The transcript levels of different adipogenesis related transcription factors, lipogenic enzymes, and lipolytic enzymes were also evaluated by quantitative real-time PCR.

Result: Phytochemical analysis demonstrated that TILE is enriched with a substantial level of polyphenols (287.20 \pm $9.21 \mathrm{mg} \mathrm{GAE} / \mathrm{g}$ extract) and flavonoids (107.52 $\pm 11.12 \mathrm{mg}$ QE/g extract) which might be the reason of significant antioxidant and radical scavenging activities. Feeding of TILE ( $400 \mathrm{mg} / \mathrm{kg} /$ day) to HFD-fed rats increased activity of superoxide dismutase and catalase which is reflected as a significant reduction of oxidative stress markers like nitric oxide and malondialdehyde. TILE (400 mg/kg/day) feeding also down-regulated the mRNA levels of proadipogenic transcription factors including liver $X$ receptor alpha (LXRa), peroxisome proliferator-activated receptor gamma (PPARY), and sterol regulatory element-binding protein 1c (SREBP1C) in diet-induced obese rats. As a consequence of this, the mRNA level of lipogenic enzymes like acetyl-CoA carboxylase (ACC), fatty acid synthase (FAS), diacylglycerol acyltransferase (DGAT), and HMG-CoA reductase was down-regulated with a parallel up-regulation of the transcript level of lipolytic enzyme, hormone-sensitive lipase (HSL).

Conclusion: Observations from this study indicate that antioxidant-rich TILE can reduce HFD-induced body weight, fat weight and liver weight as well as blood lipids through down-regulating the gene expression of proadipogenic transcription factors and lipogenic enzymes with a concerted diminution of the gene expression of lipolytic enzyme, HSL.

Keywords: Tamarindus indica, Dyslipidemia, LDL-cholesterol, Oxidative stress, Gene expression

\footnotetext{
* Correspondence: ashraful.alam@northsouth.edu;

khan.ferdous@northsouth.edu

'Department of Pharmaceutical Sciences, North South University, Dhaka

1229, Bangladesh

Full list of author information is available at the end of the article
}

\section{Springer Open}

(c) The Author(s). 2020 Open Access This article is licensed under a Creative Commons Attribution 4.0 International License, which permits use, sharing, adaptation, distribution and reproduction in any medium or format, as long as you give appropriate credit to the original author(s) and the source, provide a link to the Creative Commons licence, and indicate if changes were made. The images or other third party material in this article are included in the article's Creative Commons licence, unless indicated otherwise in a credit line to the material. If material is not included in the article's Creative Commons licence and your intended use is not permitted by statutory regulation or exceeds the permitted use, you will need to obtain permission directly from the copyright holder. To view a copy of this licence, visit http://creativecommons.org/licenses/by/4.0/. 


\section{Introduction}

Obesity, hypercholesterolemia and associated cardiovascular diseases contribute to a high percentage of morbidity and mortality in humans, making them major areas of public health interest [1]. While the synthesis of lipid-lowering drugs has been made possible in the last few decades through a plethora of scientific endeavors, in many cases, their adverse effects outweigh their benefits. For this reason, in last few decades, research interest has diverted towards the study of natural compounds such as medicinal plants, for the potential discovery of phytochemicals with the efficacy to lower lipid and glucose levels. Since the beginning of human civilization, various plant parts including flowers, fruits, leaves, roots, and barks are being used in virtually all cultures as a medicinal source due to their efficacy in treating various disorders [2]. For example, Tamarindus indica L., (family Fabaceae) is a common plant of tropical countries with medicinal, commercial and dietary importance. The brown sticky pulp of $T$. indica fruit is a very popular culinary additive in many recipes of India due to its sour and sweet taste which is attributed to the high concentration of tartaric acid and reducing sugars [3]. Historically, all across the world, almost every part of $T$. indica, but especially its fruits, leaves, seeds, and bark have been used as traditional medicine with several pharmacological applications [4]. Studies have shown that these parts of $T$. indica contain many compounds of therapeutic interest, including polyphenolic antioxidant molecules, caffeic acid and vitamin C [5]. For example, the ethanolic extract from the fruit's pericarp reduced total and non-HDL cholesterol as well as triglyceride levels, while increased HDL-cholesterol levels in hamsters, as a result of its antioxidant activities [6]. The ethyl acetate and ethanol extracts of $T$. indica seed coat have been reported to possess antioxidant [7] and anti-inflammatory properties [8]. In a clinical trial, the powdered pulp of $T$. indica fruit was found to lower effectively the level of LDL-cholesterol and total cholesterol [9]. Moreover, in another study, the extract of $T$. indica seed was reported as effective in lowering blood sugar levels in hyperglycemic male rats [10].

In the pathophysiology of adipogenesis, both dietary and genetic factors play very important roles. Among the genetic factors, liver X receptor alpha (LXR $\alpha)$ plays a critical role by regulating the gene expression of two important transcription factors related to adipogenesis like peroxisome proliferators-activated receptor gamma (PPAR $\gamma$ ), and sterol regulatory element-binding protein 1c (SREBP 1c) [11]. PPAR $\gamma$ and CCAAT enhancer-binding protein alpha $(\mathrm{C} / \mathrm{EBP} \alpha)$ controls the expression of down-stream adipocyte specific proteins and thus promotes the commitment of preadipocytes to lipid-laden matured adipocytes $[12,13]$. On the other hand, SREBP1c controls the gene expression of vital lipogenic enzymes acetyl-CoA carboxylase (ACC), fatty acid synthase (FAS), and HMG-
CoA reductase which are involved in the biosynthesis of de novo fatty acids, triacylglycerol (TG), and cholesterols [14-16]. Hence, any promising therapeutic intervention having antiobesity effect warrants the investigation of the gene expression of the abovementioned factors and enzymes to decode the molecular mechanism of action. Previous clinical and preclinical studies, through the investigation of biochemical parameters, have reported that different parts of $T$. indica L. have anti-oxidant, lipidlowering [17], blood pressure and blood glucose-lowering properties [4]. However, there is a lack of information about the efficacy of $T$. indica L. leaf extract in regulating the expression of transcription factors that control adipocyte differentiation and enzymes which participate in lipid metabolism. Without exploring the gene expression of these abovementioned transcription factors and enzymes, the molecular mechanism of $T$. indica L. leaf extract would remain obscure. This study was designed to explore the effects of ethanolic extract of T. indica L. leaf on highfat diet-fed obese Wistar rats by investigating biochemical parameters and gene expression pattern of transcription factors perform vital functions in the differentiation of adipocytes and enzymes involved in the lipid metabolism.

\section{Materials and methods} Chemicals and reagents

5,5' -dithio-bis-[2-nitrobenzoic acid] (DTNB), sulfanilamide, $\mathrm{N}$-ethyl diaminedihydrochloride (NED), nitrobluetetrazolam (NBT), thiobarbituric acid (TBA), 2,2-Diphenyl-1picrylhydrazyl (DPPH), trichloroacetic acid (TCA), gallic acid, quercetin, and trolox were purched from Sigma Aldrich (Massachusetts, USA). Kits for the assay of serum triglyceride, total cholesterol, and HDL cholesterol were of Plasmatec (Stafford, UK). GeneJET RNA Purification Kit, RevertAid First Strand cDNA Synthesis Kit and SYBR Green qPCR Master Mix were from Thermo-Fisher Scientific (Massachusetts, USA). Other chemicals used in different experiments were of high purity and of analytical grade.

\section{Tamarindus indica L. leaf-extract preparation}

Mature leaves of Tamarindus indica L. was collected from localities in Bangladesh in the mid of July. The plant species was confirmed by a botanical taxonomist of Bangladesh National Herbarium, Mirpur, Dhaka, Bangladesh (Accession No. 55785). The leaves were oven-dried at $40^{\circ} \mathrm{C}$ and pulverized into fine particles using a laboratory mill. Each portion of $100 \mathrm{~g}$ powder was immersed in $500 \mathrm{ml}$ ethanol for 7 days with continuous shaking and then filtered by Whatman filter paper (No. 41). The residue was extracted once again and filtered in the same way. All the filtrate was collected and condensed at $60{ }^{\circ} \mathrm{C}$ in a rotary evaporator and then dried under vacuum. In this way, $6.42 \mathrm{~g}$ dried extract was prepared from each of the $100 \mathrm{~g}$ dried powder of $T$. 
indica leaf. The collected extract was kept in the refrigerator at $-4{ }^{\circ} \mathrm{C}$ for further use.

\section{Quantification of total phenolic and flavonoid content in $T$. indica $L$. leaf extract}

In order to measure the phenolic and flavonoid content $50 \mathrm{mg}$ crude extract was mixed with $5 \mathrm{ml}$ of distilled water and the resulting mixture was further diluted with distilled water get a final concentration of $0.5 \mathrm{mg} / \mathrm{ml}$. Folin-Ciocalteu method was employed to measure the extract's phenolic content [18]. Briefly, $100 \mu \mathrm{L}$ leaf extract, $500 \mu \mathrm{L}$ of Folin-Ciocalteu reagent and $400 \mu \mathrm{L}$ of $7.5 \%$ sodium bicarbonate were mixed according to the mentioned sequence and the resulting mixture was incubated at $40^{\circ} \mathrm{C}$ for $20 \mathrm{~min}$. Absorbance was taken at 755 $\mathrm{nm}$ using a spectrophotometer against a blank and total phenol content was calculated in $\mathrm{mg} / \mathrm{g}$ using a standard curve of gallic acid. The flavonoid content was assayed by mixing $1 \mathrm{ml}$ crude extract with $4 \mathrm{ml}$ of deionized water and $0.3 \mathrm{ml}$ of $5 \% \mathrm{NaNO}_{2}$ solution. After $5 \mathrm{~min}, 3$ $\mathrm{ml}$ of $2 \% \mathrm{AlCl}_{3}$ solution was mixed which was followed by the addition of $2 \mathrm{ml}$ of $\mathrm{NaOH}(1 \mathrm{M})$ solution. Then it was mixed properly and absorbance was recorded at $510 \mathrm{~nm}$ against a blank. The amount of total flavonoid was estimated as $\mu \mathrm{g} / \mathrm{g}$ using quercetin as standard [19].

\section{Assessment of antioxidant and radical scavenging capacity}

The ferric reducing antioxidant power (FRAP) of the extract was carried out spectrophotometrically (at $593 \mathrm{~nm}$ ), according to the method used by Pulido et al. [20]. The results are expressed as $\mu$ mole $\mathrm{Fe}^{++} / \mathrm{g}$ dry extract. Radical scavenging property of $T$. indica L. leaf extract was quantified based on its ability to decolorize $\mathrm{ABTS}^{+}\left[2,2^{\prime}\right.$-azinobis(3-ethylbenzothiazoline-6-sulfonic acid)] cation. The absorbance was recorded at $734 \mathrm{~nm}$ and antioxidant activity was calculated using the equation obtained from trolox standard curve and was expressed as mmol Trolox/g of the dry extract [21].

The 2,2-diphenyl-1-1picrylhydrazyl (DPPH•) radicalscavenging activity of the extract was measured according to the method of Braca et al. [22]. Briefly, leaf extract of different concentrations were added to $0.004 \%(\mathrm{w} / \mathrm{v})$ solution of DPPH. The absorbance values were measured at $517 \mathrm{~nm}$ after the mixtures were incubated for $30 \mathrm{~min}$ in a light protected container. The percentage inhibition of activity was determined using the equation-

$$
\text { \%inhibition }=\frac{\left(\mathrm{A}_{0}-\mathrm{A}_{\mathrm{E}}\right)}{\mathrm{A}_{0}} \times 100
$$

Where, $A_{0}$ is the absorbance of the control, and $A_{E}$ is the absorbance of the leaf extract or of the standards. The inhibition curve was prepared by plotting percent inhibition against concentration and median inhibitory concentration $\left(\mathrm{IC}_{50}\right)$ values were calculated.

\section{Experimental design, animal feeding and diet} Healthy 9-10 weeks old male Wistar rats $(180 \pm 10 \mathrm{~g}$ body weight) were collected from the Animal Care Unit, Department of Pharmaceutical Sciences, North South University, Bangladesh. They were housed in individual cages which were kept in a room of standard environmental conditions (temperature $23 \pm 2{ }^{\circ} \mathrm{C}$, and $12 \mathrm{~h}$ light/ dark cycle) with uninterrupted access to food and water. Moreover, for ensuring their comfort and to reduce suffering all the protocols used in this study was approved by the Ethical Review Committee of the Department of Pharmaceutical Sciences, North South University, Bangladesh (ACE-0017-2018). Rats were organized into 5 groups randomly and each group consisted of 7 rats.

Group-1 (SD): Fed with standard laboratory diet (SD)

Group-2 (HFD): Fed with high-fat diet

Group-3 (HFD + TILE100): Fed with HFD and T.

indica leaf extract $(100 \mathrm{mg} / \mathrm{kg} /$ day $)$

Group-4 (HFD + TILE200): Fed with HFD and T.

indica leaf extract $(200 \mathrm{mg} / \mathrm{kg} /$ day $)$

Group-5 (HFD + TILE400): Fed with HFD and T.

indica leaf extract $(400 \mathrm{mg} / \mathrm{kg} /$ day $)$

The formula and preparation method of the standard laboratory diet (SD) and high-fat diet (HFD) were obtained from a previous report [23]. Food intake and change of body weight were calculated according to a method described earlier [24].

\section{Collection of blood, adipose tissues, and liver}

The rats were sacrificed after 8 week of treatment and blood was collected by from the heart. Collected blood was centrifuged $(8000 \times \mathrm{g})$ for $15 \mathrm{~min}$ at $4{ }^{\circ} \mathrm{C}$ for separation of serum which was immediately stored at $-20^{\circ} \mathrm{C}$ for further experiment. The liver was carefully cleared and adhering adipose tissue was separated and properly weighed. The visceral fat adhered to different internal organs were collected carefully, rinsed with phosphatebuffered saline, and then weights were measured. Weight of the liver and different adipose tissues were expressed in relation to per $100 \mathrm{~g}$ of body weight according to the method described earlier [25].

\section{Measurement of plasma lipid-related parameters}

The lipid parameters in the samples including total cholesterol (TC), triacylglycerol (TG), and high-density lipoprotein cholesterol (HDL-C) were measured by the diagnostic kits of Plasmatec Laboratories, (Allington, UK). The concentration of very-low-density lipoprotein cholesterol 
(VLDL-C) and low-density lipoprotein cholesterol (LDL-C) was calculated by Firedewald formula [26]:

$$
\begin{aligned}
& \mathrm{VLDL}-\mathrm{C}=\frac{\mathrm{TG}}{5} \\
& \mathrm{LDL}-\mathrm{C}=\mathrm{TC}-(\mathrm{HDL}-\mathrm{C}+\mathrm{VLDL}-\mathrm{C})
\end{aligned}
$$

Moreover, atherogenic index (AI) and coronary risk index (CRI) were calculated by the formula [27].

$$
\begin{aligned}
& \text { Athorogenic index }(\mathrm{AI})=\frac{\text { Non }-\mathrm{HDLC}}{\mathrm{HDL}-\mathrm{C}} \\
& \text { Coronery risk index }(\mathrm{CRI})=\frac{\mathrm{TC}}{\mathrm{HDL}-\mathrm{C}}
\end{aligned}
$$

\section{Measurement of oxidative stress-related parameters and antioxidant enzymes' activity}

Lipid peroxidation was assessed by measuring the level of malondialdehyde based on its ability to interact with thiobarbituric acid which can be detected and quantified spectrophotometrically at $532 \mathrm{~nm}$ [28]. Nitric oxide (NO) level was measured by mixing the samples collected from blood and liver with Griess reagent which contains $1.5 \%$ sulfanilamide in $1 \mathrm{~N} \mathrm{HCl}$ and $1 \% \mathrm{~N}$-(1-)naphthylethylenediamine (NED) in $\mathrm{H}_{2} \mathrm{O}$. The resulting pink colored mixture was evaluated by a spectrophotometer (at $548 \mathrm{~nm}$ ) and the concentration of $\mathrm{NO}$ was calculated by a standard curve of sodium nitrite [29]. The activity of superoxide dismutase was measured according to the process developed by Kakkar et al. with some customizations [30]. Briefly, the reaction mixture contained $25 \mathrm{mM}$ sodium phosphate buffer, 0.186 $\mathrm{mM}$ phenazine methosulphate and $0.3 \mathrm{mM}$ nitroblue tetrazolium with $0.1 \mathrm{ml}$ of sample collected from blood or liver. Then $0.7 \mathrm{mM}$ reduced nicotinamide adenine dinucleotide (NADH) was added and the mixture was kept at $30^{\circ} \mathrm{C}$ for $90 \mathrm{~s}$. After that, it was mixed with $1.0 \mathrm{ml}$ glacial acetic acid and $4 \mathrm{ml} \mathrm{n}$-butanol and then the mixture was let stand for $10 \mathrm{~min}$ before centrifugation. Absorbance of the collected supernatant was taken at $560 \mathrm{~nm}$ against $\mathrm{n}$-butanol blank. The activity of catalase was measured by mixing the plasma sample to $30 \mathrm{mM} \mathrm{H}_{2} \mathrm{O}_{2}$ and $50 \mathrm{mM}$ phosphate buffer (pH 7.0) and by recording the absorbance at $230 \mathrm{~nm}$ according to a previously described method [31].

\section{Gene expression of transcription factors and fat metabolizing proteins}

Total mRNA, from the mesenteric adipose tissue sample, was extracted by GeneJET RNA Purification Kit (ThermoFisher Scientific, Massachusetts, USA) for checking the transcript level of adipocyte-specific marker genes. After measuring the concentration, $1 \mu \mathrm{g}$ mRNA was used in reverse transcription reaction for synthesizing cDNA using RevertAid First Strand cDNA Synthesis Kit (Thermo-Fisher Scientific, USA) in a Thermal Cycler (Takara Bio Inc.,
Ohtsu, Japan). Using this cDNA as a template, the transcript level of adipogenesis related transcription factors and enzymes were quantified by real-time PCR using $2 \mathrm{X}$ SYBR Green qPCR Master Mix (Thermo Scientific, USA) and forward and reverse primers designed by Primer3 online software (Table 1). The PCR reaction was conducted in a CFX96 TouchTM Real-Time PCR Detection System (BioRad Laboratories Inc., California, USA) and data were analyzed by CFX ManagerTM software (Bio-Rad, California, USA). The PCR was carried out at $95^{\circ} \mathrm{C}$ for 1 min followed by 40 cycles for amplification: $95^{\circ} \mathrm{C}(5 \mathrm{~s})$ for denaturation, $60^{\circ} \mathrm{C}(30 \mathrm{~s})$ for annealing, and $72^{\circ} \mathrm{C}(1 \mathrm{~min})$ for synthesis which was followed by the final extension at $72^{\circ} \mathrm{C}$ for 5 min. The transcript level of each of the target protein was relatively quantified by normalization to the transcript level of $\beta$-actin.

\section{Histology of hepatic tissue}

A suitable section of the liver from a representative rat of each group was collected, after measuring the weight the liver, and was kept in neutral buffered formalin (pH -7.4). For visualization and estimation of lipid accumulation within the hepatocytes, the liver tissue from a particular group of the rat was embedded on paraffin, cut as thin layer $(5 \mu \mathrm{m})$ with a microtome, was stained with haematoxylin and eosin (H\&E) according to standard histological process described earlier [32]. Photomicrograph was taken using a differential interference optical microscope (Model-ZEISS-AXIO, Carl Zeiss Microimaging, Jena Germany). Lipid area percentages were quantified from a different group of animals using ImageJ software (version 1.52a).

\section{Statistical analysis}

All phytochemical analyses were done in triplicate $(n=3)$, biochemical and gene expression analyses were done in sextuplicate $(n=6)$ and the data were expressed as mean \pm SEM. For the determination of significant change among different groups, data were interpreted by one-way ANOVA and Newman-Kuels post hoc test by Graph Pad Prism.

\section{Results}

Quantification of polyphenols, flavonoids content and evaluation of relative antioxidant property of $T$. indica $\mathrm{L}$. leaf extract

The antioxidant property of $T$. indica leaf extract (TILE) was close to that of butylated hydroxytoluene (BHT) which might be attributed to its higher level of polyphenols $(287.20 \pm 9.21 \mathrm{mg} \mathrm{GAE} / \mathrm{g}$ extract) and flavonoids (107.52 \pm $11.12 \mathrm{mg} Q \mathrm{QE} / \mathrm{g}$ extract). But the antioxidant activity of TILE was significantly lower than that of quercetin and ascorbic acid as was revealed in DPPH and ABTS radical scavenging activities and ferric reducing activity (Table 2). 
Table 1 The forward and reverse sequence of the primers used in this study

\begin{tabular}{|c|c|c|}
\hline Gene (GeneBank accession no.) & Type & Sequence \\
\hline \multirow[t]{2}{*}{ C/EBPa (NM_001287579.1) } & Forward & 5'-GCCAAGAAGTCGGTGGATAA-3' \\
\hline & Reverse & 5'- CCTTGACCAAGGAGCTCTCA-3' \\
\hline \multirow[t]{2}{*}{ PPARY (NM_013124.3) } & Forward & 5'-CCCTGGCAAAGCATTTGTAT-3' \\
\hline & Reverse & 5'-GAAACTGGCACCCTTGAAAA-3' \\
\hline \multirow[t]{2}{*}{ LXRa (NM_031627.2) } & Forward & 5'-GCTCCTTCTCTGACCGACTT-3' \\
\hline & Reverse & 5'-GTCTTCAGCAAGGCGATCTG-3' \\
\hline \multirow[t]{2}{*}{ SREBP1C (NM_001276707.1) } & Forward & 5'-GGCATGAAACCTGAAGTGGT-3' \\
\hline & Reverse & 5'-TGCAGGTCAGACACAGGAAG-3' \\
\hline \multirow[t]{2}{*}{ FAS (M84761.1) } & Forward & 5'-TCGAGACACATCGTTTGAGC-3' \\
\hline & Reverse & 5'-CTCAAAAAGTGCATCCAGCA-3' \\
\hline \multirow[t]{2}{*}{ ACC (NM_053437.1) } & Forward & 5'-ACAACGCAGGCATCAGAAGA-3' \\
\hline & Reverse & 5'-GCTGTGCTGCAGGAAGATTG-3' \\
\hline \multirow[t]{2}{*}{ DGAT-2 (NM_053437.1) } & Forward & 5'-TGAATTGGTGCGTGGTGATG-3' \\
\hline & Reverse & 5'-GACAGGCGCTTCTCAATCTG-3' \\
\hline \multirow[t]{2}{*}{ HMGCR (NM_013134.2) } & Forward & 5'-CATGCTGCCAACATCGTCA-3' \\
\hline & Reverse & 5'-TTGTGGGACTTGCTTC-3' \\
\hline \multirow[t]{2}{*}{ ATGL (NM_001108509.2) } & Forward & 5'- CTCGAGTITCGGATGGAGAG-3' \\
\hline & Reverse & 5'- TGAGAATGGGGACACTGTGA-3' \\
\hline \multirow[t]{2}{*}{ HSL (NM_012859.1) } & Forward & 5'- TAGCTGGAGGTGGTTCTGCT-3' \\
\hline & Reverse & 5'-CCAGTTACCATCTTCAGTGTAG-3' \\
\hline \multirow[t]{2}{*}{ MAGL (NM_138502.2) } & Forward & 5'- CACCTCTGATCCTTGCCAAT-3' \\
\hline & Reverse & 5'- GATGAGTGGGTCGGAGTTGT-3' \\
\hline \multirow[t]{2}{*}{$\beta$-Actin (V01217.1) } & Forward & 5'- AGCCATGTACGTAGCCATCC-3' \\
\hline & Reverse & 5'- CTCTCAGCTGTGGTGGTGAA-3' \\
\hline
\end{tabular}

Food intake, body weight, and adipose tissue weight

The relationship between food intake, body weight gain, wet weight of liver and fat weight of different parts are represented in Table 3. The data suggests that HFD-induced increase of body weight, liver weight, and fat weight are not related to the amount of food consumed per day rather these are related to the composition of the food. Feeding of ethanolic extract of $T$. indica leaf (TILE) up to the level of $200 \mathrm{mg} / \mathrm{kg}$ everyday for 8 weeks was unable to reduce the HFD-induced body weight, fat weight and liver weight significantly. But TILE administration of $400 \mathrm{mg} / \mathrm{kg}$ was successful in reducing body weight, liver weight, mesenteric and peritoneal fat weights significantly $(p<0.05)$.

\section{Assessment of plasma lipid profile}

Feeding of HFD caused in a significant $(p<0.05)$ increase of TG, TC, LDL-C, VLDL-C, atherogenic index (AI) and coronary risk index (CRI) in comparison to standard laboratory diet $(\mathrm{SD})$ fed group. On the other hand, the plasma level of HDL-C was reduced significantly $(p<0.05)$ due to the feeding of HFD. Oral administration of $100 \mathrm{mg} /$ $\mathrm{kg}$ and $200 \mathrm{mg} / \mathrm{kg}$ ethanolic extract of $T$. indica leaf (TILE)

Table 2 In vitro antioxidant activities of the ethanolic extract of T. indica leaf

\begin{tabular}{lllll}
\hline & $\begin{array}{l}\text { Polyphenol } \\
\text { content } \\
(\mathbf{m g ~ G A E} / \mathbf{g})\end{array}$ & $\begin{array}{l}\text { Flavonoid } \\
\text { content } \\
(\mathbf{m g ~ Q E} / \mathbf{g})\end{array}$ & $\begin{array}{l}\text { DPPH radical scavenging } \\
\text { activity, IC } \\
(\boldsymbol{\mu g} / \mathbf{m l})\end{array}$ & $\begin{array}{l}\text { ABTS radical scavenging } \\
\text { activity } \\
(\mathbf{m m o l e} \text { Trolox/g) }\end{array}$ \\
\hline $\begin{array}{l}\text { T. indica leaf } \\
\text { extract }\end{array}$ & $287.20 \pm 9.21$ & $107.52 \pm 11.12$ & $26.54 \pm 3.18^{\mathrm{a}}$ & $1.61 \pm 0.12^{\mathrm{a}}$ \\
BHT & $\mathrm{NA}$ & $\mathrm{NA}$ & $29.17 \pm 2.34^{\mathrm{a}}$ & $1.79 \pm 0.08^{\mathrm{a}}$ \\
Ascorbic acid & $\mathrm{NA}$ & $\mathrm{NA}$ & $11.02 \pm 0.82^{\mathrm{b}}$ & $5.07 \pm 0.05^{\mathrm{b}}$ \\
Quercetin & $\mathrm{NA}$ & $\mathrm{NA}$ & $9.81 \pm 0.61^{\mathrm{b}}$ & $4.27 \pm 0.18^{\mathrm{c}}$ \\
\hline
\end{tabular}

Polyhenol and flavonoid content and in vitro radical scavenging and antioxidant activities of the ethanolic extract of $T$. indica L. leaf. Data was analyzed by one way ANOVA followed by Newman-Keuls's post-hoc test and expressed as mean \pm SEM $(n=3)$. Values with different superscript letters within the same column are significantly different at $p<0.05$. NA, not applicable 
Table 3 Effects of ethanolic extract T. indica L. leaf on food intake and body weight of high-fat diet induced rats

\begin{tabular}{llllll}
\hline Parameter & ND & HFD & HFD + TILE100 & HFD + TILE200 & HFD + TILE400 \\
\hline Food intake (g/day) & $18.23 \pm 2.51^{\mathrm{a}}$ & $18.51 \pm 3.11^{\mathrm{a}}$ & $20.21 \pm 2.42^{\mathrm{a}}$ & $19.41 \pm 2.92^{\mathrm{a}}$ & $19.21 \pm 2.67^{\mathrm{a}}$ \\
Percent weight gain & $39.82 \pm 4.25^{\mathrm{a}}$ & $66.27 \pm 5.42^{\mathrm{b}}$ & $62.91 \pm 7.38^{\mathrm{b}}$ & $59.72 \pm 5.32^{\mathrm{b}}$ & $45.26 \pm 4.53^{\mathrm{a}}$ \\
Liver weight (g/100 g body weight) & $3.12 \pm 0.43^{\mathrm{a}}$ & $4.83 \pm 0.63^{\mathrm{b}}$ & $4.64 \pm 0.54^{\mathrm{b}}$ & $4.52 \pm 0.57^{\mathrm{b}}$ & $3.61 \pm 0.61^{\mathrm{a}}$ \\
Epidedymal fat (g/100 g body weight) & $1.13 \pm 0.12^{\mathrm{a}}$ & $1.81 \pm 0.23^{\mathrm{b}}$ & $1.72 \pm 0.18^{\mathrm{b}}$ & $1.64 \pm 0.19^{\mathrm{b}}$ & $1.61 \pm 0.17^{\mathrm{b}}$ \\
Mesenteric fat (g/100 g body weight) & $0.73 \pm 0.08^{\mathrm{a}}$ & $1.17 \pm 0.13^{\mathrm{b}}$ & $1.02 \pm 0.12^{\mathrm{b}}$ & $0.97 \pm 0.10^{\mathrm{a}}$ & $0.84 \pm 0.11^{\mathrm{a}}$ \\
Peritoneal fat (g/100 g body weight) & $0.87 \pm 0.10^{\mathrm{a}}$ & $1.26 \pm 0.15^{\mathrm{b}}$ & $1.22 \pm 0.11^{\mathrm{b}}$ & $1.17 \pm 0.13^{\mathrm{b}}$ & $0.91 \pm 0.12^{\mathrm{a}}$ \\
\hline
\end{tabular}

Effects of Tamarindus indica L. leaf extract (TILE) on food intake, body weight gain, liver weight and adipose tissue weight in different group of Wistar rats fed with either of standard laboratory diet (SD), or high-fat diet (HFD), or HFD with TILE. TILE was given orally everyday throughout the study period either in low dose (HFD + TILE100), or intermediate dose (HFD + TILE200) or high dose (HFD + TILE400). Data was analyzed by one way ANOVA followed by Newman-Keuls's post-hoc test and expressed as mean \pm SEM $(n=6)$. Values with different superscript letters within the same row are significantly different at $p<0.05$

was not able to change these parameters. But feeding of TILE at the higher dose $(400 \mathrm{mg} / \mathrm{kg})$ caused the significant reduction of HFD-induced increased levels of TG (32.2\%), TC (25.6\%), LDL-C (34.1\%), VLDL-C (32.6\%) levels in plasma and consequently reduced $\mathrm{AI}(46.3 \%)$ and CRI (39.6\%). But feeding of TILE even at the highest dose (400 $\mathrm{mg} / \mathrm{kg}$ ) was failed to cause a significant change of HDL-C level (Table 4).

\section{In vivo antioxidant effects of $T$. indica L. leaf extract}

The level of malondialdehyde (MDA) increased 1.83 folds and the level of nitric oxide $(\mathrm{NO})$ increased by 2.66 -folds in the blood due to 8 weeks long feeding of a HFD comparison to the rats fed on standard laboratory diet (SD). Additionally, the HFD-mediated increase of MDA and NO levels were accompanied by a significant $(p<0.05)$ fall of superoxide dismutase (SOD) (56.2\%) and catalase (49.7\%) activities. Consumption of ethanolic extract of Tamarindus indica leaf (TILE) at low dose $(100 \mathrm{mg} / \mathrm{kg} /$ day $)$ was not able to reduce the level of MDA and NO markedly. But feeding of TILE at the highest dose $(400 \mathrm{mg} / \mathrm{kg} /$ day $)$ caused a significant $(\mathrm{p}<0.05)$ reduction of MDA $(39.7 \%)$ and NO (35.3\%) levels in comparison to the HFD-fed rats (Fig. 1). Similarly, feeding of TILE at low level $(100 \mathrm{mg} / \mathrm{kg} /$ day $)$ was unable to increase the reduced SOD and catalase activities markedly. But consumption of TILE at the highest level ( $400 \mathrm{mg} / \mathrm{kg} /$ day) significantly increased the SOD (1.97 fold) and catalase (1.89 folds) activities in comparison to the HFD-fed rats. Moreover, catalase activity was also increased significantly due to feeding of TILE at intermediated level (200 mg/kg/day) (Fig. 1).

\section{T. indica leaf extract down-regulated the gene expression of adipogenesis promoting transcription factors}

This part of our study was aimed to investigate the impact of $T$. indica leaf extract on the gene expression of these four important transcription factors like PPAR $\gamma, \mathrm{CCAAT} / \mathrm{en}$ hancer-binding protein $\alpha \mathrm{C} / \mathrm{EBP} \alpha, \mathrm{LXR} \alpha$, and SREBP1c which regulates numerous proteins, enzymes and factor that control the conversion of preadipocytes to matured adipocytes and fat metabolism. Our investigation revealed that feeding with a HFD significantly $(P<0.05)$ upregulated the gene expression of LXR $\alpha$ (2.41 folds), PPAR $\gamma$ (1.98 folds), C/EBP $\alpha$ (2.11 folds), and SREBP1c (2.13 folds) in comparison to SD fed rats. Consumption of TILE at low $(100 \mathrm{mg} / \mathrm{kg})$ dose was unable to change the HFD-induced increased mRNA level. Feeding of TILE at moderate dose $(200 \mathrm{mg} / \mathrm{kg} /$ day) together with HFD reduced the mRNA level of LXR $\alpha$ and SREBP1c significantly. Consumption of TILE at highest dose $(400 \mathrm{mg} / \mathrm{kg})$ every day for 8 weeks significantly $(p<0.05)$ lowered the transcript level of all the above mentioned factors except C/EBP $($ Fig. 2).

Table 4 Effect of high-fat diet and ethanolic extract of T. indica L. leaf on lipid profile of rats

\begin{tabular}{llllll}
\hline Parameter & ND & HFD & HFD + TILE100 & HFD + TILE200 & HFD + TILE400 \\
\hline TG $(\mathrm{mg} / \mathrm{dl})$ & $121.81 \pm 13.33^{\mathrm{a}}$ & $216.37 \pm 21.57^{\mathrm{b}}$ & $211.42 \pm 22.17^{\mathrm{b}}$ & $199.43 \pm 23.63^{\mathrm{b}}$ & $145.82 \pm 19.23^{\mathrm{a}}$ \\
TC $(\mathrm{mg} / \mathrm{dl})$ & $198.21 \pm 23.84^{\mathrm{a}}$ & $274.23 \pm 25.34^{\mathrm{b}}$ & $268.05 \pm 31.34^{\mathrm{b}}$ & $242.54 \pm 34.39^{\mathrm{b}}$ & $205.35 \pm 24.47^{\mathrm{a}}$ \\
$\mathrm{HDL}-\mathrm{C}(\mathrm{mg} / \mathrm{dl})$ & $62.33 \pm 6.72^{\mathrm{a}}$ & $41.27 \pm 6.98^{\mathrm{b}}$ & $47.64 \pm 7.45^{\mathrm{b}}$ & $50.67 \pm 5.43^{\mathrm{b}}$ & $51.31 \pm 6.53^{\mathrm{b}}$ \\
LDL-C $(\mathrm{mg} / \mathrm{dl})$ & $111.27 \pm 14.58^{\mathrm{a}}$ & $189.71 \pm 17.32^{\mathrm{b}}$ & $178.87 \pm 19.37^{\mathrm{b}}$ & $152.21 \pm 19.34^{\mathrm{a}}$ & $125.56 \pm 14.49^{\mathrm{a}}$ \\
VLDL-C (mg/dl) & $24.52 \pm 3.65^{\mathrm{a}}$ & $43.34 \pm 5.67^{\mathrm{b}}$ & $42.13 \pm 6.37^{\mathrm{b}}$ & $39.72 \pm 5.43^{\mathrm{b}}$ & $29.22 \pm 4.51^{\mathrm{a}}$ \\
Al & $2.19 \pm 0.21^{\mathrm{a}}$ & $5.65 \pm 0.71^{\mathrm{b}}$ & $4.58 \pm 0.63^{\mathrm{b}}$ & $3.84 \pm 0.34^{\mathrm{c}}$ & $3.05 \pm 0.42^{\mathrm{c}}$ \\
CRI & $3.19 \pm 0.61^{\mathrm{a}}$ & $6.65 \pm 0.81^{\mathrm{b}}$ & $5.58 \pm 0.71^{\mathrm{b}}$ & $4.84 \pm 0.37^{\mathrm{c}}$ & $4.05 \pm 0.54^{\mathrm{a}}$
\end{tabular}

Effects of $T$. indica L. leaf extract (TILE) on lipid related parameters in different group of Wistar rats fed with either of standard laboratory diet (SD), or high-fat diet (HFD), or HFD with TILE. TILE was given orally everyday throughout the study period either in low dose (HFD + TILE100), or intermediate dose (HFD + TILE200) or high dose (HFD + TILE400). Data was analyzed by one way ANOVA followed by Newman-Keuls's post-hoc test and expressed as mean \pm SEM $(n=6)$. Values with different superscript letters within the same row are significantly different at $p<0.05$ 
A. Malondialdehyde

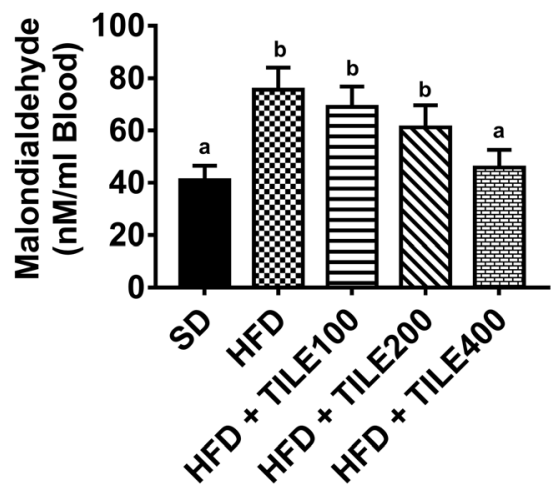

C. SOD activity

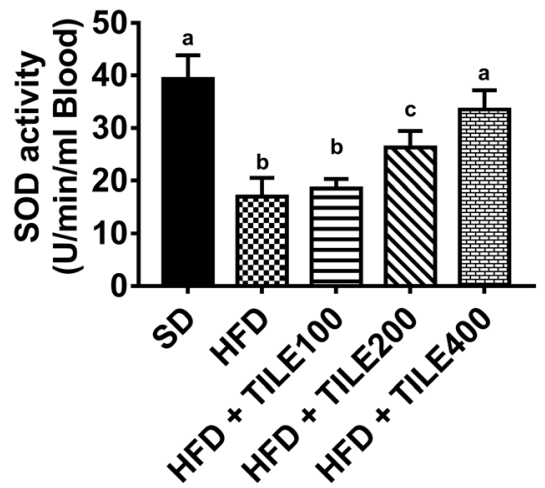

B. Nitric oxide

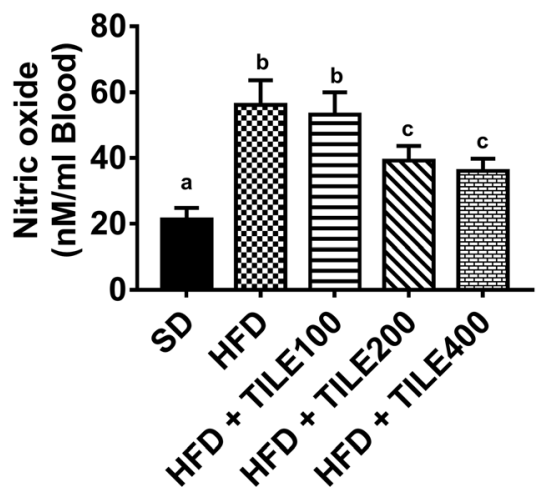

D. Catalase activity

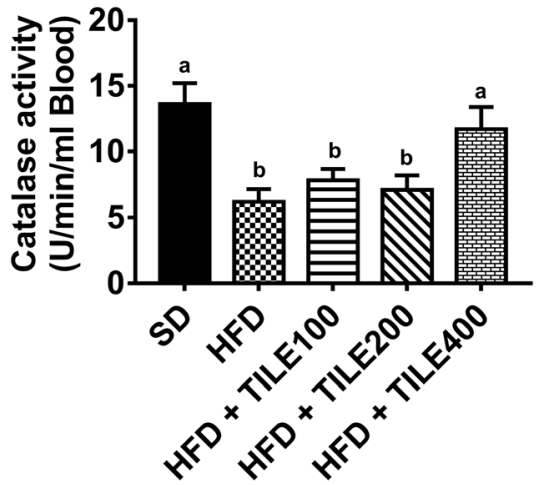

Fig. 1 Effects of ethanolic extract of T. indica L. leaf (TILE) on (a) malondialdehyde (MDA), (b) nitric oxide (NO), (c) superoxide dismutase (SOD) activity, and (d) catalse activity in different group of Wistar rats fed with either of standard laboratory diet (SD), or high-fat diet (HFD), or HFD with TILE. TILE was given orally everyday throughout the study period either in low dose (HFD + TILE100), or intermediate dose (HFD + TILE200) or high dose (HFD + TILE400). Data was analyzed by one way ANOVA followed by Newman-Keuls's post-hoc test and expressed as mean \pm SEM $(n=$ 6). Values with different superscript letters within the same row are significantly different at $p<0.05$

Effect of $T$. indica leaf extract on the gene expression of lipogenic and lipolytic enzymes

To get a deeper understanding the effect of $T$. indica extract on the transcript levels of lipogenic and lipolytic enzymes were also analyzed in quantitative real-time PCR after extraction of mRNA from different groups of test animals. This part of the study demonstrated that consumption of HFD resulted in augmented transcription of ACC, FAS, DGAT-2, and HMGCR by 2.32 folds, 1.91 folds 2.21 folds and 2.61 folds respectively, in comparison to rats fed on SD. Administration of $T$. indica leaf extract at low level (100 $\mathrm{mg} / \mathrm{kg}$ ) was unable to change the HFD-induced augmentation of this gene expression of lipogenic enzymes. However, consumption of TILE at highest dose significantly $(p<0.05)$ lowered of the transcript level of ACC (35.7\%), FAS (36.4\%), DGAT-2 (33.7\%), and HMGCR (52.3\%) compared to HFD group (Fig. 3). Moreover, feeding of TILE at intermediate dose $(200 \mathrm{mg} / \mathrm{kg})$ significantly $(p<0.05)$ reduced the gene expression of DGAT-2 and HMGCR (Fig. 3). On the other hand, in HFD consuming rats, the mRNA levels of lipolytic enzymes like hormone-sensitive lipase (HSL), adipose triglyceride lipase (ATGL) and monoacylglycerol lipase (MAGL) were reduced significantly $(p<0.05)$ in comparison to the rats which received SD. Treatment with TILE even at the highest dose $(400 \mathrm{mg} / \mathrm{kg}$ ) for 8 weeks was unable to change the transcript levels of ATGL and MAGL. But feeding of TILE, both at intermediate dose and high dose significantly $(p<0.05)$ increased HFD-inhibited level of HSL (Fig. 4).

Histological assessment of adipogenesis in hepatic tissue The anti-adipogenic effect of T. indica leaf extract (TILE) on HFD-induced fat accumulation is demonstrated by the photomicrographs of hepatic tissues from different group of rats (Fig. 5a-e). The liver tissue from the rats fed on standard laboratory diet showed very little amount of lipid accumulation which was increased significantly $(p<0.05)$ 
A. $L X R \alpha$

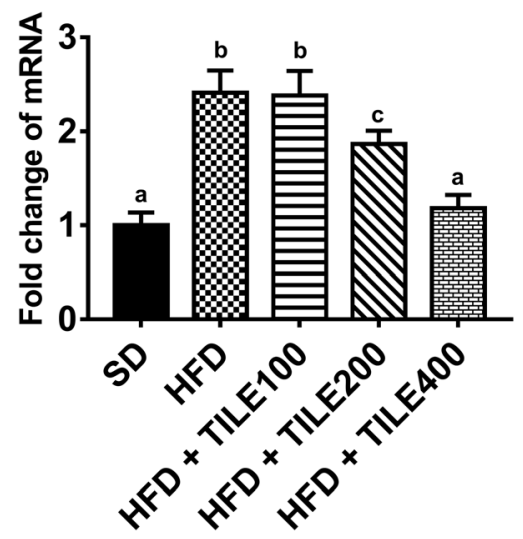

C. $\mathrm{C} / \mathrm{EBP} \alpha$

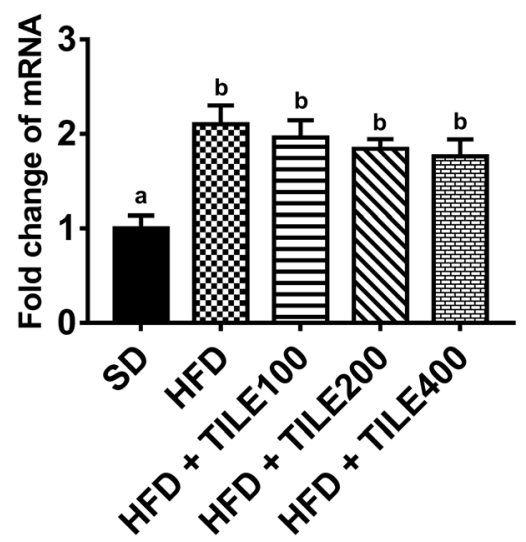

B. PPAR $\gamma$

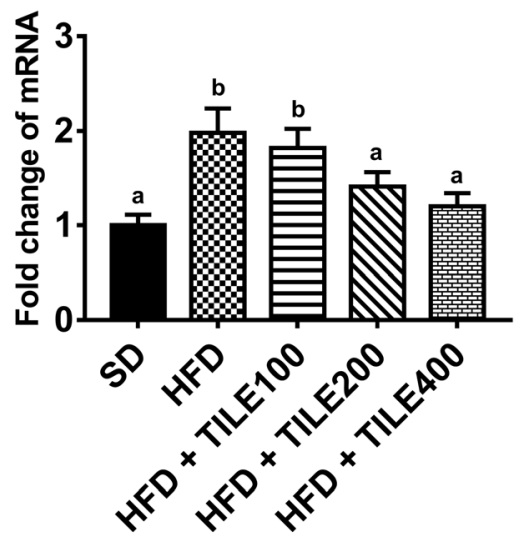

\section{SREBP1C}

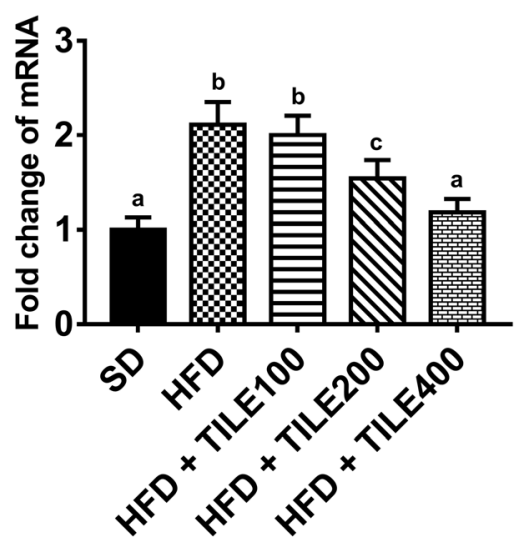

Fig. 2 Comparison of liver $X$ receptor alpha ( $L X R a)$, peroxisome proliferator-activated receptor gamma (PPARY), CCAAT enhancer binding protein alpha (C/EBPa), and sterol regulatory element binding protein 1c (SREBP1c) and gene expression in epididymal adipose tissue in different group of Wistar rats fed with either of standard laboratory diet (SD), or high-fat diet (HFD), or HFD with TILE. TILE was given orally everyday throughout the study period either in low dose (HFD + TILE100), or intermediate dose (HFD + TILE200) or high dose (HFD + TILE400). Data was analyzed by one way ANOVA followed by Newman-Keuls's post-hoc test and expressed as mean \pm SEM $(n=6)$. Values with different superscript letters within the same row are significantly different at $p<0.05$

due to feeding of HFD. Rats consumed HFD with TILE in lower dose and intermediate dose showed an insignificant reduction of lipid accumulation in comparison to the HFD-fed group. However, feeding of TILE at higher dose together with HFD prevented the lipid deposition significantly $(p<0.05)$ (Fig. 5f).

\section{Discussion}

Generally in physiological conditions, the level of prooxidants and antioxidants are equilibrated in a balanced condition which might be disturbed by overproduction of reactive oxygen species (ROS) and/or feeble antioxidant defense and may cause oxidative stress [33]. This imbalance can be a major risk factor of metabolic derangement which leading to the conditions like dyslipidemia, obesity, hypertension, insulin resistance and diabetes mellitus [34]. Studies have confirmed a strong connection between high-fat diet consumption and oxidative stress in both humans and in other animals [35]. For example, obesity induced by a high-fat diet has been linked to oxidative stress which causes overproduction of oxidized LDLcholesterol that plays vital role in the pathogenesis of dyslipidemia, atherosclerosis and other cardiovascular diseases [36]. Therefore, we postulated that any plant extract having antioxidant properties could be a good option for the treatment of ailments related to oxidative stress. Our present investigation revealed that $T$. indica leaf extract has an antioxidant property which is equivalent to BHT but significantly lower than quercetin and ascorbic acid (Table 2). This was in agreement with the reports where 
A. ACC

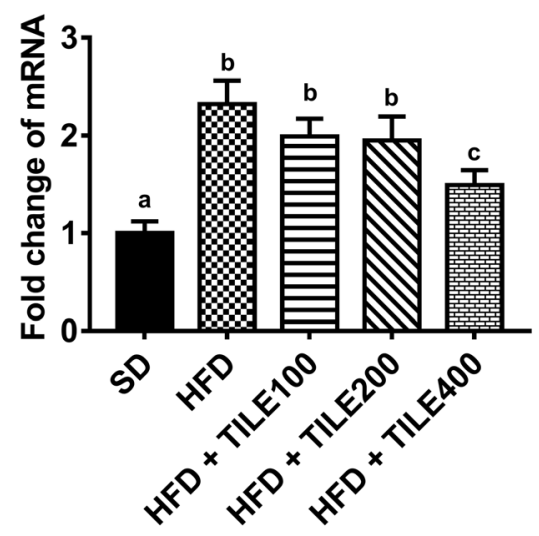

C. DGAT-2

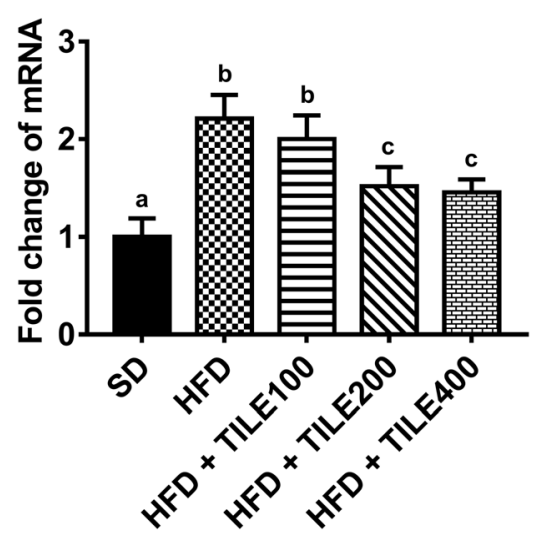

B. FAS

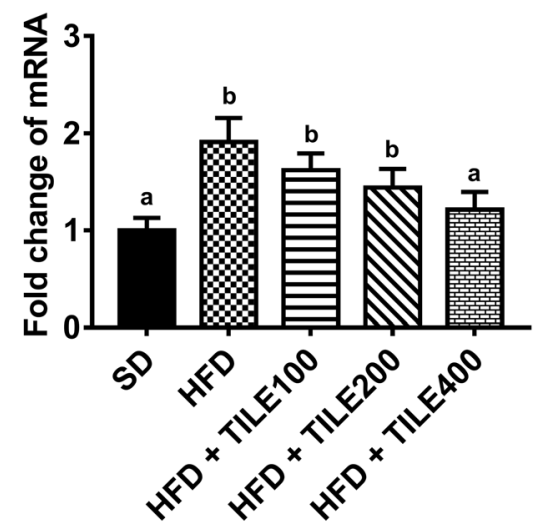

\section{HMGCR}

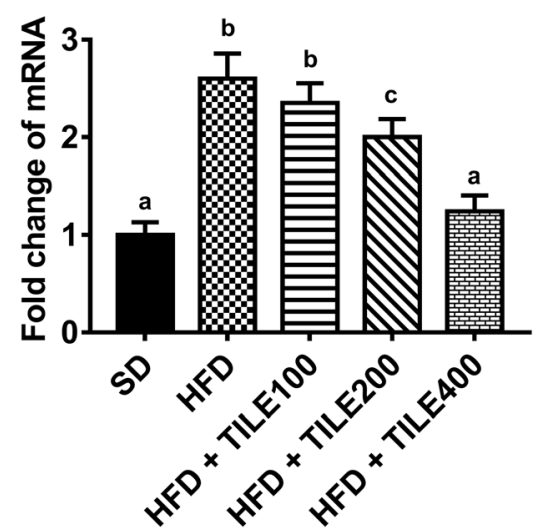

Fig. 3 Comparison of transcript level of acetyl-CoA carboxylase (ACC), fatty acid synthase (FAS), diacylglycerol acyltransferase 2 (DGAT-2), and HMG-CoA reductase (HMGCR) in epididymal adipose tissue in different group of Wistar rats fed with either of standard laboratory diet (SD), or high-fat diet (HFD), or HFD with TILE. TILE was given orally everyday throughout the study period either in low dose (HFD + TILE100), or intermediate dose (HFD + TILE200) or high dose (HFD + TILE400). Data was analyzed by one way ANOVA followed by Newman-Keuls's post-hoc test and expressed as mean $\pm \operatorname{SEM}(n=6)$. Values with different superscript letters within the same row are significantly different at $p<0.05$

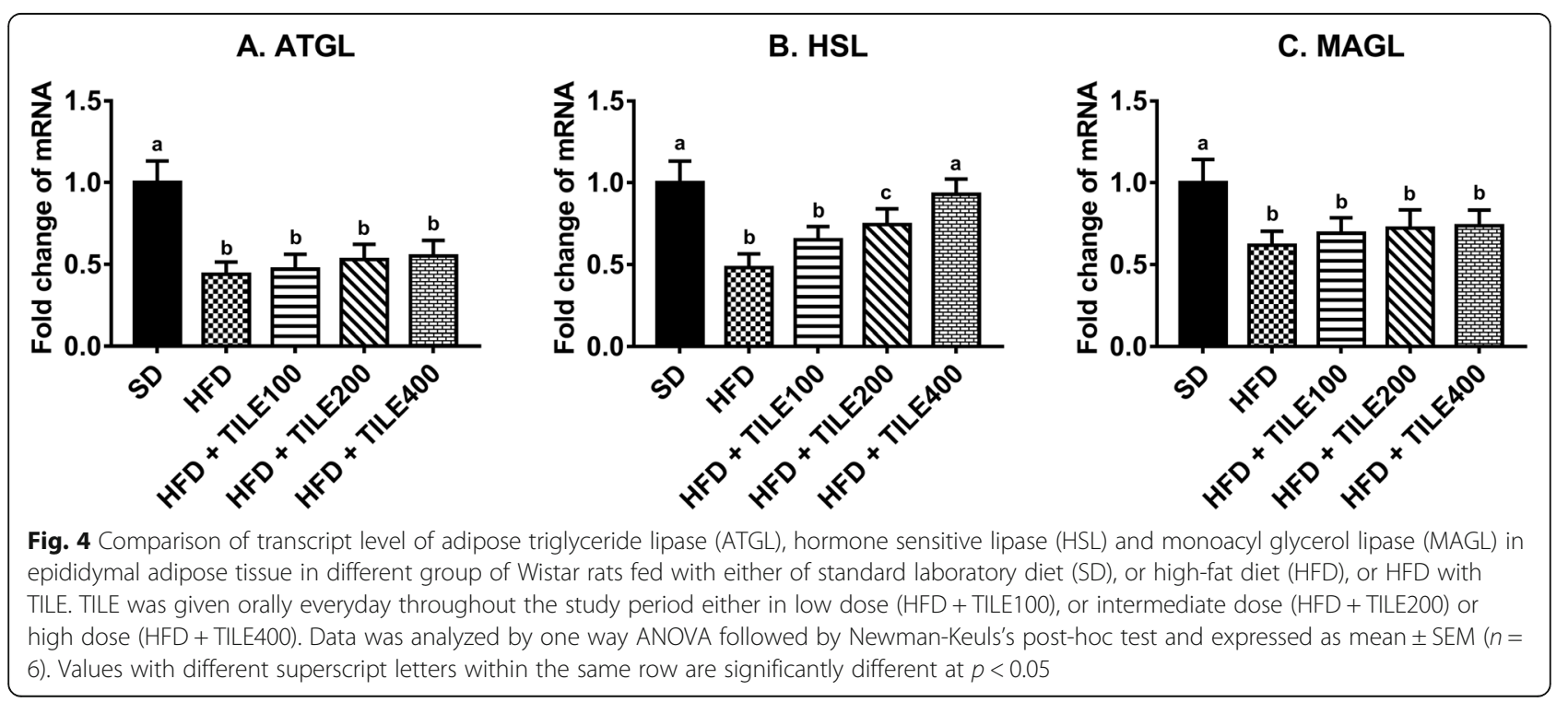




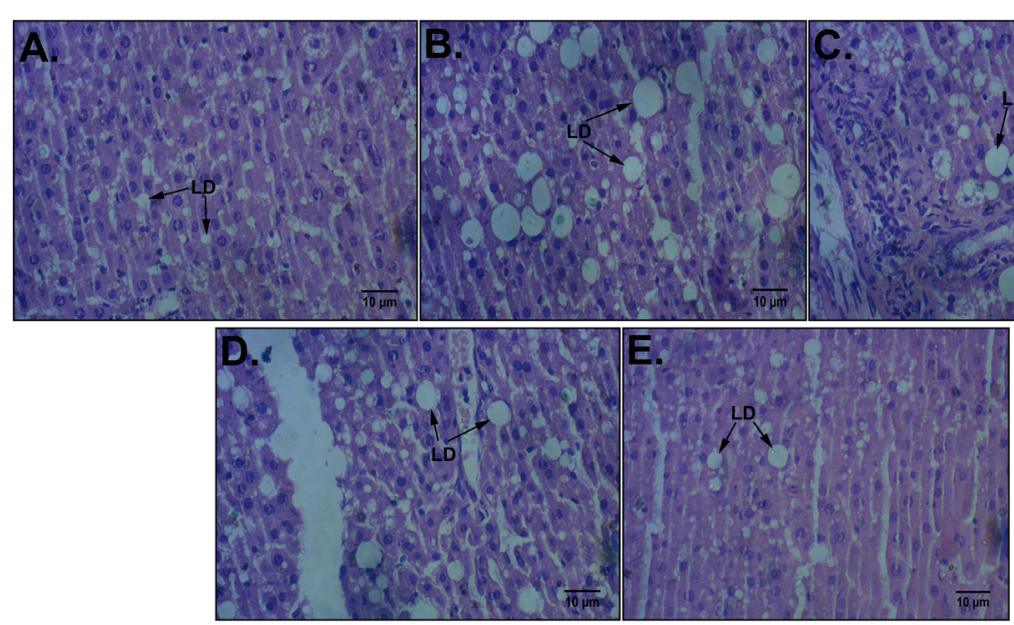

F.

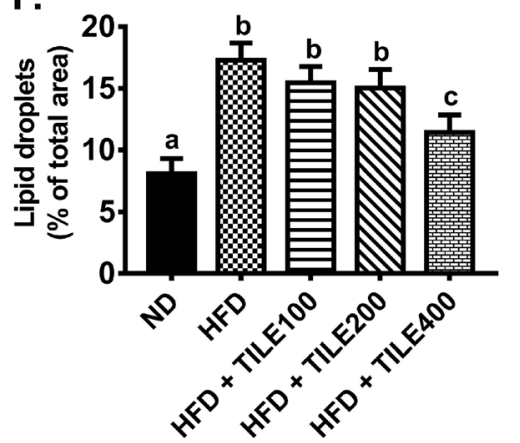

Fig. 5 Comparison of lipid accumulation in the liver of Wistar rats which was fed with either of standard laboratory diet (SD), or high-fat diet (HFD), or HFD with TILE. TLLE was given orally everyday throughout the study period either in low dose (HFD + TLLE100), or intermediate dose (HFD + TILE200) or high dose (HFD + TLE400). Photomicrographs (a-e) showing lipid droplets (LD) are representative one of the 3 experiments for a particular group. Additionally, percent lipid accumulation (f) was quantified by ImageJ software (version 1.52a). Data was analyzed by one way ANOVA followed by Newman-Keuls's post-hoc test and expressed as mean $\pm \operatorname{SEM}(n=6)$. Values with different superscript letters within the same row are significantly different at $p<0.05$

phytochemical analysis confirmed that different parts of $T$. indica are full of antioxidant compounds like procyanidin B2, epicatechin, tartaric acid, limonene, longifoline, kaempferol, etc. [37]. More specifically, the leaves of $T$. indica contain some powerful antioxidant compounds including limonene, vitamin $C, \beta$-carotene, flavonoids, and different polyphenols [38]. In agreement with in vitro antioxidant and radical scavenging activity $T$. indica leaf extract was also shown to possess strong antioxidant property in vivo. This study demonstrated that $T$. indica leaf extract can reduce high-fat diet-induced elevated levels of nitric oxide and malondialdehyde which was accompanied by augmented activities of major antioxidant enzymes like superoxide dismutase and catalase (Fig. 1). This antioxidant power of $T$. indica leaf might be attributed to a higher level of total polyphenols and flavonoids found in the ethanolic extract (Table 2). Polyphenolic compounds can inhibit the activity of xanthine oxidase enzyme which is involved in the production of superoxide radicals and stimulation of antioxidant enzymes' activity [39]. Our observations showed similarity with a previous report where an ethanolic extract of T. indica leaf suppressed the generation of ROS and lipid peroxidation while enhanced the antioxidant enzymes' activity and thus reversed oxidative stress-induced damage in HepG2 cells [40].

The polyphenolic compounds can act as an antioxidant through direct interaction with both radical and nonradical type ROS as well as indirectly by modulating the gene expression of proteins and enzymes having antioxidant activity [41]. Therefore, our next objective was to evaluate the efficiency of polyphenolic compound-rich $T$. indica leaf extract to ameliorate dyslipidemia, and fat storage in HFD-induced obese Wistar rats through controlling the gene expression of adipocyte differentiation-related transcription factors, lipogenic and lipolytic enzymes. In the 8 weeks long feeding period, $T$. indica leaf extract was able to reduce HFD-induced increased body weight, liver weight, mesenteric and peritoneal adipose tissue weight (Table 3) with the simultaneous lowering of TG, TC, LDL-C and VLDL-C (Table 4). That increase of lipid in the blood triggered the increase of fat accumulation in the hepatic tissue as was revealed in the photomicrographs 
taken after hematoxylin and eosin staining (Fig. 5). Our findings were in agreement with another report where the extract of $T$. indica seeds was shown to have potent plasma lipid and glucose-lowering activities in streptozotocin-induced diabetic rats [10]. However, our observations were slightly different from another report where $T$. indica aqueous pulp extract considerably reduced serum cholesterol, body weight, and LDL-C but increased HDL-C and triglycerides in normal chow diet-fed healthy rats [42].

Obesity is a lipid metabolism disorder that involves the participation of diverse genetic and dietary factors. Over the last few years, considerable progress has been accomplished in the conceptualization of molecular mechanism of adipogenesis. Proper mapping of transcriptional regulation and identification of pro- and anti-adipogenic endogenous factors is therefore vital in decoding the molecular mechanism of any therapeutic intervention of obesity and associated health issues [43]. Among those factors, PPAR $\gamma$ and C/EBP $\alpha$ are the transcription factors that have very important functions in the conversion of preadipocytes to matured adipocytes [44]. These two factors up-regulate the expression of downstream adipocytespecific factors, enzymes, and proteins. For this reason, these two are regarded as the master regulators of adipogenesis [45]. The gene expression of PPAR $\gamma$ is controlled by up-stream transcription factor LXR $\alpha$ which also controls the expression of another vital transcription factor SREBP1c [46]. Studies have reported that SREBP1c by interacting with specific sterol regulatory element sequences of DNA enhances the expression of enzymes like ACC, FAS and HMGCR and thus enhances lipogenesis [47]. Therefore, we hypothesized that the anti-adipogenic effect of antioxidant-rich $T$. indica leaf extract might have been mediated through controlling the gene expression of the above-mentioned transcription factors and enzymes. By considering the objective of delving deeper into the molecular mechanism, we explored the gene expression of those pre-adipocyte differentiation-related transcription factors and some important lipogenic and lipolytic enzymes which are directly or indirectly controlled by those factors. This part of our investigation revealed that administration of T. indica leaf extract reduced the gene expression of LXR $\alpha$, and its down-stream PPAR $\gamma$ and SREBP1c significantly $(P<0.05)$, all of which were augmented due to feeding of HFD (Fig. 2). Similar pattern of changes have been reported in previous studies where researchers found that crude plant extracts reduced diet-induced augmented gene expression of PPAR $\gamma$ in rats which resulted in the reduced plasma level of TG and reduced body weight $[48,49]$.

Among the lipogenic enzymes, ACC and FAS are directly modulated by SREBP1c and play the most vital roles in fatty acid biosynthesis [50]. On the other hand,
DGAT catalyzes the biosynthesis of triglyceride [51]. Additionally, the expression of HMGCR enzyme that catalyzes the most important step in cholesterol biosynthesis was also explored. Our investigation revealed that feeding to $T$. indica leaf extract significantly suppressed the HFD-induced augmented mRNA levels of ACC, FAS, DGAT-2, and HMGCR (Fig. 3). Thus our findings were in agreement with another report where researchers using the Syrian hamster as model animal demonstrated that anti-obesity effect of $T$. indica fruit pulp might be attributed to the suppression of HMGCoA reductase gene expression [17]. On the other hand, ATGL, HSL, and MAGL are the most important enzymes involved in TG catabolism in adipose and other tissues [52, 53]. Our study revealed that the high-fat diet-mediated suppression of HSL was normalized significantly $(P<0.05)$ due to the feeding of $400 \mathrm{mg} / \mathrm{kg}$ T. indica leaf extract daily for 8 weeks (Fig. 4).

\section{Conclusion}

This study demonstrated that oral administration of antioxidant-rich Tamarindus indica L. leaf extract (TILE) for 8 weeks significantly reduced the HFD-induced oxidative stress by increasing the activities of antioxidant enzymes. TILE also down-regulated the mRNA levels of adipogenesis controlling transcription factors and lipogenic enzymes with a parallel up-regulation of the transcript level of lipolytic enzyme, HSL. Consistently, TILE reduced the amount of TG, TC, LDL-C and VLDL-C in the serum with an orchestrated lowering of adipose tissue weight, liver weight and body weight.

\section{Abbreviations \\ ACC: actyl-CoA carboxylase; ATGL: adipose triglyceride lipase; C/EBPa: CCAA T-enhancer-binding protein a; DGAT: diacylglycerol acyltransferase; FAS: fatty acid synthase; FRAP: ferric reducing antioxidant power; GPx: glutathione peroxidase; HDL-C: high-density lipoprotein cholesterol; HFD: high-fat diet; HMGCR: 3-hydroxy-3-methyl-glutaryl-coenzyme A reductase; HSL: hormone- sensitive lipase; LDL-C: low-density lipoprotein cholesterol; LXRa: liver X receptor-a; MAGL: monoacylglycerol lipase; PPARY: peroxisome proliferator- activated receptor- $\gamma$; RT-PCR: reverse-transcription polymerase chain reaction; SOD: superoxide dismutase; SREBP: sterol regulatory element-binding protein; TC: total cholesterol; TG: triacylglycerol or triglyceride; TILE: ethanolic extract of Tamarindus indica L. leaf extract; VLDL-C: very-low-density lipoprotein cholesterol}

\section{Acknowledgments}

The authors are grateful to the chairman, Department of Pharmaceutical Sciences, North South University Dhaka-1229, Bangladesh and to the director, North South University Genome Research Institute, Dhaka-1229, for allowing us to use the laboratory instruments.

\section{Authors' contributions}

SAK and MIB performed biochemical assays; NS and MHS prepared the extract and performed antioxidant assay; AR and MMH extracted RNA and did the quantitative real-time PCR; MAA and FK designed the study and prepared the manuscript. All authors checked and approved the final version of this manuscript. 


\section{Funding}

This work was funded by North South University Research Grant Cycle 20182019 awarded to Dr. Ferdous Khan (CTRG code: NSU-RP-18-013). The authors are also grateful to the Department of Pharmaceutical Sciences, North South University and North South University Genome Research Institute for their helpful gestures to conduct the research.

\section{Availability of data and materials}

The corresponding author is entitled to provide the data upon reasonable request.

\section{Ethics approval and consent to participate}

The study protocol was approved by Ethical Review Committee of the Department of Pharmaceutical Sciences, North South University, Bangladesh (Ref No.: ACE-0017-2018).

\section{Consent for publication}

Not applicable.

\section{Competing interests}

The authors declare that they have no competing interests.

\section{Author details}

'Department of Pharmaceutical Sciences, North South University, Dhaka 1229, Bangladesh. ${ }^{2}$ North South University Genome Research Institute (NGRI), Dhaka 1229, Bangladesh.

Received: 15 April 2020 Accepted: 23 September 2020

Published online: 15 October 2020

\section{References}

1. Khan TJ, Ahmed YM, Zamzami MA, Mohamed SA, Khan I, Baothman OA, et al. Effect of atorvastatin on the gut microbiota of high fat diet-induced hypercholesterolemic rats. Sci Rep. 2018;8(1):662 https://doi.org/10.1038/ s41598-017-19013-2.

2. Petrovska BB. Historical review of medicinal plants' usage. Pharmacogn Rev. 2012:6(11):1-5 https://doi.org/10.4103/0973-7847.95849.

3. Devarajan A, Mohanmarugaraja M. A comprehensive review on Rasam: a south Indian traditional functional food. Pharmacogn Rev. 2017;11(22):73 https://doi.org/10.4103/phrev.phrev_13_17.

4. Bhadoriya SS, Ganeshpurkar A, Narwaria J, Rai G, Jain AP. Tamarindus indica: extent of explored potential. Pharmacogn Rev. 2011;5(9):73 https://doi.org/ 10.4103/0973-7847.79102.

5. Sudjaroen $Y$, Haubner R, Würtele G, Hull W, Erben G, Spiegelhalder B, et al. Isolation and structure elucidation of phenolic antioxidants from tamarind (Tamarindus indica L.) seeds and pericarp. Food Chem Toxicol. 2005;43(11): 1673-82 https://doi.org/10.1016/j.fct.2005.05.013.

6. Martinello F, Soares S, Franco JJ, Santos ACd, Sugohara A, Garcia SB, et al, Hypolipemic and antioxidant activities from Tamarindus indica L. pulp fruit extract in hypercholesterolemic hamsters. Food Chem Toxicol 2006;44(6): 810-818. https://doi.org/10.1016/j.fct.2005.10.011.

7. Luengthanaphol S, Mongkholkhajornsilp D, Douglas S, Douglas PL. Pengsopa L-i, Pongamphai S. extraction of antioxidants from sweet Thai tamarind seed coat--preliminary experiments. J Food Eng. 2004;63(3):24752 https://doi.org/10.1016/j.foodeng.2003.07.006.

8. Ushanandini S, Nagaraju S, Harish Kumar K, Vedavathi M, Machiah D, Kemparaju $\mathrm{K}$, et al. The anti-snake venom properties of Tamarindus indica (leguminosae) seed extract. Phytother Res. 2006;20(10):851-8 https://doi.org/10.1002/ptr.1951.

9. Iftekhar A, Rayhan I, Quadir MA, Akhteruzzaman S, Hasnat A. Effect of Tamarindus indica fruits on blood pressure and lipid-profile in human model: an in vivo approach. Pak J Pharm Sci. 2006;19(2):125-9.

10. Maiti $R$, Jana $D$, Das $U$, Ghosh D. Antidiabetic effect of aqueous extract of seed of Tamarindus indica in streptozotocin-induced diabetic rats. $J$ Ethnopharmacol. 2004;92(1):85-91 https://doi.org/10.1016/j.jep.2004.02.002.

11. Seo JB, Moon HM, Kim WS, Lee YS, Jeong HW, Yoo EJ, et al. Activated liver $X$ receptors stimulate adipocyte differentiation through induction of peroxisome proliferator-activated receptor $y$ expression. Mol Cell Biol. 2004; 24(8):3430-44 https://doi.org/10.1128/mcb.24.8.3430-3444.2004.

12. Shao X, Wang M, Wei X, Deng S, Fu N, Peng Q, et al. Peroxisome proliferatoractivated receptor-y: master regulator of adipogenesis and obesity. Curr Stem Cell Res Ther. 2016;11(3):282-9 https://doi.org/10.2174/1574888×10666150528144905.
13. Rosen ED, Hsu C-H, Wang X, Sakai S, Freeman MW, Gonzalez FJ, et al. C/ EBPa induces adipogenesis through PPARy: a unified pathway. Genes Dev. 2002;16(1):22-6 https://doi.org/10.1101/gad.948702.

14. Tang X, Li J, Xiang W, Cui Y, Xie B, Wang X, et al. Metformin increases hepatic leptin receptor and decreases steatosis in mice. J Endocrinol. 2016; 230(2):227-37 https://doi.org/10.1530/joe-16-0142.

15. Xu X, So J-S, Park J-G, Lee A-H, editors. Transcriptional control of hepatic lipid metabolism by SREBP and ChREBP. Seminars in liver disease; 2013: Thieme Medical Publishers. https://doi.org/10.1055/s-0033-1358523.

16. Ferre P, Foufelle F. SREBP-1c transcription factor and lipid homeostasis: clinical perspective. Horm Res Paediatr. 2007;68(2):72-82 https://doi.org/10. $1159 / 000100426$.

17. Lim CY, Junit SM, Abdulla MA, Aziz AA. In vivo biochemical and gene expression analyses of the antioxidant activities and hypocholesterolaemic properties of Tamarindus indica fruit pulp extract. PLoS One. 2013;8(7): e70058 https://doi.org/10.1371/journal.pone.0070058.

18. Noreen $\mathrm{H}$, Semmar N, Farman M, McCullagh JS. Measurement of total phenolic content and antioxidant activity of aerial parts of medicinal plant Coronopus didymus. Asian Pac J Trop Med. 2017;10(8):792-801 https://doi. org/10.1016/j.apjtm.2017.07.024.

19. Baba SA, Malik SA. Determination of total phenolic and flavonoid content, antimicrobial and antioxidant activity of a root extract of Arisaema jacquemontii Blume. J Taibah Univ Sci. 2015;9(4):449-54 https://doi.org/10. 1016/j.jtusci.2014.11.001.

20. Pulido R, Bravo L, Saura-Calixto F. Antioxidant activity of dietary polyphenols as determined by a modified ferric reducing/antioxidant power assay. J Agric Food Chem. 2000;48(8):3396-402 https://doi.org/10.1021/jf9913458.

21. Re R, Pellegrini N, Proteggente A, Pannala A, Yang M, Rice-Evans C. Antioxidant activity applying an improved ABTS radical cation decolorization assay. Free Radic Biol Med. 1999:26(9-10):1231-7 https://doi.org/10.1016/s0891-5849(98)00315-3.

22. Braca A, \& Tommasi N, Di BL, Pizza C, \& Politi M, Morelli, I. Antioxidant principles from Bauhinia terapotensis. J Nat Prod. 2001; 64. 892-5.

23. Choi H-K, Won E-K, Jang YP, Choung S-Y. Antiobesity effect of Codonopsis lanceolata in high-calorie/high-fat-diet-induced obese rats. Evid Based Complement Alternat Med. 2013;2013 https://doi.org/10.1155/2013/210297.

24. Akase T, Shimada T, Terabayashi S, Ikeya Y, Sanada H, Aburada M. Antiobesity effects of Kaempferia parviflora in spontaneously obese type II diabetic mice. J Nat Med. 2011;65(1):73-80 https://doi.org/10.1007/s11418-010-0461-2.

25. Kim S-J, Jung JY, Kim HW, Park T. Anti-obesity effects of Juniperus chinensis extract are associated with increased AMP-activated protein kinase expression and phosphorylation in the visceral adipose tissue of rats. Biol Pharm Bull. 2008;31(7):1415-21 https://doi.org/10.1248/bpb.31.1415.

26. Martin SS, Blaha MJ, Elshazly MB, Toth PP, Kwiterovich PO, Blumenthal RS, et al. Comparison of a novel method vs the Friedewald equation for estimating lowdensity lipoprotein cholesterol levels from the standard lipid profile. JAMA. 2013;310(19):2061-8 https://doi.org/10.1001/jama.2013.280532.

27. Kazemi T, Hajihosseini M, Moossavi M, Hemmati M, Ziaee M. Cardiovascular risk factors and Atherogenic indices in an Iranian population: Birjand east of Iran. Clin Med Insights Cardiol. 2018;12:1179546818759286 https://doi.org/ $10.1177 / 1179546818759286$.

28. Zeb A, Ullah F. A simple spectrophotometric method for the determination of thiobarbituric acid reactive substances in fried fast foods. J Anal Methods Chem. 2016;2016 https://doi.org/10.1155/2016/9412767.

29. Ghasemi A, Hedayati M, Biabani H. Protein precipitation methods evaluated for determination of serum nitric oxide end products by the Griess assay. JMSR. 2007;2(15):29-32.

30. Kakkar P, Das B, Viswanathan P. A modified spectrophotometric assay of superoxide dismutase. 1984. Indian J Biochem Biophys. 1984;21(2):130-2.

31. Hadwan MH. Simple spectrophotometric assay for measuring catalase activity in biological tissues. BMC Biochem. 2018;19(1):7 https://doi.org/10. 1186/s12858-018-0097-5.

32. Noratto GD, Lage NN, Chew BP, Mertens-Talcott SU, Talcott ST, Pedrosa ML. Non-anthocyanin phenolics in cherry (Prunus avium L.) modulate IL-6, liver lipids and expression of PPARS and LXRs in obese diabetic $(\mathrm{db} / \mathrm{db})$ mice. Food Chem. 2018;266:405-14 https://doi.org/10.1016/j.foodchem.2018.06.020.

33. Birben E, Sahiner UM, Sackesen C, Erzurum S, Kalayci O. Oxidative stress and antioxidant defense. World Allergy Organ J. 2012;5(1):9 https://doi.org/10. 1097/wox.0b013e3182439613.

34. Tangvarasittichai S. Oxidative stress, insulin resistance, dyslipidemia and type 2 diabetes mellitus. World J Diabetes. 2015;6(3):456 https:/doi.org/10.4239/wjd.v6.i3.456. 
35. Duan $Y$, Zeng L, Zheng C, Song B, Li F, Kong $X$, et al. Inflammatory links between high fat diets and diseases. Front Immunol. 2018;13(9):2649 https://doi.org/10.3389/fimmu.2018.02649.

36. Mashima R, Witting PK, Stocker R. Oxidants and antioxidants in atherosclerosis. Curr Opin Lipidol. 2001;12:411-8 https:/doi.org/10.1097/00041433-200108000-00007.

37. Bhadoriya S, Mishra V, Raut S, Ganeshpurkar A, JAIN S. Anti-inflammatory and antinociceptive activities of a hydroethanolic extract of Tamarindus indica leaves. Sci Pharm. 2012;80(3):685-700 https://doi.org/10.3797/scipharm.1110-09.

38. Escalona-Arranz JC, Péres-Roses R, Urdaneta-Laffita I, Camacho-Pozo MI, Rodríguez-Amado J, Licea-Jiménez I. Antimicrobial activity of extracts from Tamarindus indica L. leaves. Pharmacogn Mag. 2010;6(23):242-7 https://doi. org/10.4103/0973-1296.66944

39. Rodrigo R, Miranda A, Vergara L. Modulation of endogenous antioxidant system by wine polyphenols in human disease. Clin Chim Acta. 2011;412(56):410-24 https://doi.org/10.1016/i.cca.2010.11.034

40. Razali N, Aziz AA, Lim CY, Junit SM. Investigation into the effects of antioxidant-rich extract of Tamarindus indica leaf on antioxidant enzyme activities, oxidative stress and gene expression profiles in HepG2 cells. PeerJ. 2015;3:e1292 https://doi.org/10.7717/peerj.1292.

41. Stoclet J-C, Chataigneau T, Ndiaye M, Oak M-H, El Bedoui J, Chataigneau M, et al. Vascular protection by dietary polyphenols. Eur J Pharmacol. 2004; 500(1-3):299-313 https://doi.org/10.1016/.ejphar.2004.07.034.

42. Jindal V, Dhingra D, Sharma S, Parle M, Harna RK. Hypolipidemic and weight reducing activity of the ethanolic extract of Tamarindus indica fruit pulp in cafeteria diet-and sulpiride-induced obese rats. J Pharmacol Pharmacother. 2011;2(2):80-4 https://doi.org/10.4103/0976-500x.81896.

43. Lefterova MI, Lazar MA. New developments in adipogenesis. Trends Endocrinol Metab. 2009;20(3):107-14 https://doi.org/10.1016/.tem.2008.11.005.

44. Lefterova MI, Zhang Y, Steger DJ, Schupp M, Schug J, Cristancho A, et al. PPARY and C/EBP factors orchestrate adipocyte biology via adjacent binding on a genome-wide scale. Genes Dev. 2008;22(21):2941-52 https:/doi.org/ 10.1101/gad.1709008.

45. Madsen MS, Siersbæk R, Boergesen M, Nielsen R, Mandrup S. Peroxisome proliferator-activated receptor $\gamma$ and C/EBPa synergistically activate key metabolic adipocyte genes by assisted loading. Mol Cell Biol. 2014;34(6): 939-54 https://doi.org/10.1128/mcb.01344-13.

46. Seo JB, Moon HM, Noh MJ, Lee YS, Jeong HW, Yoo EJ, et al. Adipocyte determination-and differentiation-dependent factor $1 /$ sterol regulatory element-binding protein $1 \mathrm{c}$ regulates mouse adiponectin expression. J Biol Chem. 2004;279(21):22108-17 https://doi.org/10.1074/jbc.m400238200.

47. Kidani $Y$, Bensinger SJ. Liver $X$ receptor and peroxisome proliferator-activated receptor as integrators of lipid homeostasis and immunity. Immunol Rev. 2012; 249(1):72-83 https:/doi.org/10.1111/j.1600-065x.2012.01153.x.

48. Lestari SR, Djati MS, Rudijanto A, Fatchiyah F. PPARy expression by rambutan peel extract in obesity rat model-induced high-calorie diet. Asian Pac J Trop Biomed. 2015;5(10):852-7 https://doi.org/10.1016/j.apjtb.2015.01.030

49. Kim JH, Kim OK, Yoon HG, et al. Anti-obesity effect of extract from fermented Curcuma longa $\mathrm{L}$. through regulation of adipogenesis and lipolysis pathway in high-fat diet-induced obese rats. Food Nutr Res. 2016; 60(1):30428 https://doi.org/10.3402/fnr.v60.30428.

50. Menendez JA, Vazquez-Martin A, Ortega FJ, Fernandez-Real JM. Fatty acid synthase: association with insulin resistance, type 2 diabetes, and cancer. Clin Chem. 2009;55(3):425-38 https://doi.org/10.1373/clinchem.2008.115352.

51. Yen C-LE, Stone SJ, Koliwad S, Harris C, Farese RV. Thematic review series glycerolipids. DGAT enzymes and triacylglycerol biosynthesis. J Lipid Res. 2008;49(11):2283-301 https://doi.org/10.1194/jlr.r800018-j|r200.

52. Schweiger M, Schreiber R, Haemmerle G, Lass A, Fledelius C, Jacobsen P, et al. Adipose triglyceride lipase and hormone-sensitive lipase are the major enzymes in adipose tissue triacylglycerol catabolism. J Biol Chem. 2006; 281(52):40236-41 https://doi.org/10.1074/jbc.m608048200.

53. Morak M, Schmidinger H, Riesenhuber G, Rechberger GN, Kollroser M Haemmerle G, et al. Adipose triglyceride lipase (ATGL) and hormone-sensitive lipase (HSL) deficiencies affect expression of lipolytic activities in mouse adipose tissues. Mol Cell Proteomics. 2012;11(12):1777-89 https://doi.org/10.1074/mcp. m111.015743.

\section{Publisher's Note}

Springer Nature remains neutral with regard to jurisdictional claims in published maps and institutional affiliations.

\section{Submit your manuscript to a SpringerOpen ${ }^{\circ}$ journal and benefit from:}

- Convenient online submission

- Rigorous peer review

- Open access: articles freely available online

- High visibility within the field

- Retaining the copyright to your article

Submit your next manuscript at $\boldsymbol{\nabla}$ springeropen.com 